\title{
THE FLUVIAL GEOMORPHOLOGY OF THE LOWER EBRO (2002-2013): BRIDGING GAPS BETWEEN MANAGEMENT AND RESEARCH
}

\author{
R.J. BATALLA ${ }^{1,2,3}$, D. VERICAT ${ }^{1,3,4}$, A. TENA ${ }^{1 *}$ \\ ${ }^{1}$ Fluvial Dynamics Research Group - RIUS, Department of Environment and Soil Sciences, \\ University of Lleida, E-25198 Lleida, Catalonia, Spain. \\ ${ }^{2}$ Catalan Institute for Water Research - ICRA, E-17003 Girona, Catalonia, Spain \\ ${ }^{3}$ Forest Science Centre of Catalonia - CTFC, E-25280 Solsona, Catalonia, Spain. \\ ${ }^{4}$ Institute of Geography and Earth Sciences, Aberystwyth University, Aberystwyth SY23 3FL, Wales, UK.
}

ABSTRACT. This paper summarises twelve years of research undertaken on the lower River Ebro (NE Spain). The research has been undertaken to achieve a fundamental understanding of the fluvial processes in this large Mediterranean river affected by flow regulation. Dams in the whole basin and, in particular, in the lower section of the river alter the Ebro's flow and sedimentary regimes, thus affecting its physical and ecological functioning. Data obtained on hydrology, sediment transport and river channel dynamics (i.e. particle mobility, bed structure) have aided the design and implementation of flushing flows since 2002; the main objectives of these artificial releases were the control of excess growth of aquatic vegetation (i.e. macrophytes) and the maintenance of certain sedimentary activity in the channel downstream from the Mequinenza-Ribarroja-Flix Dam complex. Results highlight the sedimentary disequilibrium of the river, with the current sediment load equating to $1 \%$ of that estimated at the beginning of the $20^{\text {th }}$ century in the absence of dams and under different land uses. Channel platform changes show that the channel has become more stable since dams were closed and a significant reduction of sediment availability has occurred, together reinforcing the sedimentary disequilibrium of the river. Monitoring of flushing flows has demonstrated their high sediment transport capacity. This suggests that, in combination with other restoration measures such as sediment injections, flushing flows could greatly benefit the riverine ecosystem, reducing macrophyte stands and maximizing the sediment delivery to the lowermost river reaches.

Geomorfología fluvial del Bajo Ebro (2002-2013): tendiendo puentes entre gestión e investigación

RESUMEN. Este artículo resume doce años de investigación sobre procesos fluviales en el bajo Ebro (NE España). La regulación a la que está sometida la cuen- 
ca y, especialmente, su tramo bajo, ha alterado los regímenes hidrológico y sedimentario del río, afectando, a su vez, a su funcionamiento físico y ecológico. Los datos hidrológicos, de transporte de sedimentos y de morfología del cauce (movilidad de partículas, estructura del lecho) han permitido, por ejemplo, diseñar y mejorar la efectividad de las crecidas de mantenimiento desde su primera ejecución en el año 2002. Los principales objetivos de estas crecidas artificiales son controlar el exceso de vegetación acuática (macrófitos) en el cauce y mantener una mínima actividad sedimentaria en el río aguas abajo del complejo de presas de Mequinenza - Ribarroja - Flix. Los resultados confirman el desequilibrio sedimentario que experimenta el tramo bajo del Ebro, siendo la carga sedimentaria transportada el $1 \%$ de la estimada a principios del siglo XX (en ausencia de presas y con usos del suelo diferentes a los actuales). Los cambios morfológicos reflejan una mayor estabilidad del lecho desde el cierre de las presas así como una significativa reducción de la disponibilidad de sedimento, hechos que han contribuido de manera significativa al fuerte déficit sedimentario que afecta a este tramo de río. La notable capacidad de transporte demostrada por las crecidas de mantenimiento sugiere que la combinación de las mismas con otras medidas de restauración, como las inyecciones de sedimento, podría mejorar el ecosistema ribereño, reduciendo la población de macrófitos y aumentando la transferencia de sedimentos al sistema deltaico.

Key words: sediment transport, sedimentary regime, flow regime, flushing flows, dams, river Ebro.

Palabras clave: transporte de sedimento, régimen sedimentario, régimen fluvial, crecidas de mantenimiento, presas, río Ebro.

Received 29 January 2014 Accepted 11 February 2014

*Corresponding author: Fluvial Dynamics Research Group - RIUS, Department of Environment and Soil Sciences, University of Lleida, E-25198 Lleida, Catalonia, Spain.E-mail: alvaro.tena@macs.udl.cat

\section{Introduction}

Rivers in natural conditions tend to maintain a long-term morphosedimentary equilibrium, whereby the amount of sediment coming from the erosion zones is equivalent to the amount deposited in the lowland zones (e.g. Williams and Wolman, 1984). Transport of sediment through the catchment and along the length of the river system can therefore be considered as quasi-continuous. However, rivers and their valleys have been modified to satisfy human demands, including navigation, agriculture and, most recently (i.e. from the 19th century onwards), damming for hydro-electric power production, water supply, flood control and industrial activities. These activities produce a series of transformations that have radically altered rivers and their associated ecosystems. 
Rivers in the Mediterranean region are highly modified, and are among the most impounded rivers in the world (Grantham et al., 2010). Dams alter river systems in two ways: (i) by modifying the flow and flood regime and (ii) by interrupting the conveyance of the solid load. In the first case, the alteration of downstream flow regime of rivers has been widely reported (e.g. Williams and Wolman, 1984; Petts, 1984, Batalla et al., 2004). The resultant hydrological alterations include changes in flood frequency and magnitude, reduction in overall flow, changes in baseflows, and flow altered patterns of fluctuation as a consequence of the timing of releases from dams. Secondly, dams disrupt the continuity of sediment transport, reducing the supply of sediment to downstream reaches. Water released from the dam may still be competent to move sediment and, under this circumstance, a sediment deficit exists and river degradation may occur through bed incision, channel narrowing and/or bed coarsening (e.g. Surian and Rinaldi, 2003; Surian and Cisotto, 2007; Vericat et al., 2006). Even if sediment supply does not completely cease, alterations in channel morphology and associated changes in river and estuarine ecosystem structure may occur (e.g. Hutchinson et al., 1995; Ligon et al., 1995).

Poulos and Collins (2002) reported a reduction of the sediment supply to the Mediterranean basin by almost 50\% since the middle of the 20th century, associated, among other reasons (e.g. changes in climate and land use), with sediment trapped in reservoirs of large rivers, such as the Po, the Rhône, and the Nile. The River Ebro is one of the large Mediterranean rivers affected by major impoundments, and associated impacts on the hydrology (i.e. Batalla et al., 2004), morphology (Batalla et al., 2006) and sediment transport (i.e. Vericat and Batalla, 2006; Batalla and Vericat, 2011; Tena and Batalla, 2013) of the river have already been identified. Moreover, the location of a large dam complex in the lowermost reaches of the river contributes to the reduction of water and sediment arriving at the river's delta and associated coastal zone.

In the last decades, scientists and water managers of the European Union have remarked the need for action to avoid long-term deterioration of freshwater environments. Within this context, the Water Framework Directive (WFD) was developed with the main objective of bring most of the European surface water bodies into good or better status by 2015. To accomplish this objective, the WFD requires each River Basin District to define a River Basin Management Plan (RBMP). By law, RBMPs must contain a programme of Measures (PoM) devoted to the improvement of the rivers' ecological status. The Ebro River Basin Management Plan indicates the need of implementing "River restoration measures based on environmental criteria" to improve (i) the morphological status and (ii) the sediment management of the lower river downstream from the dams. Against this legislative background, scientists from the University of Lleida in collaboration with the Ebro Water Authorities (CHE) and Endesa Generación SA, the hydropower company operating the dams, have been working since 2002 to design, model, implement and monitor flushing flows (hereafter FF) to improve the morphological and ecological status of the lower River Ebro. The work comprises twelve years of research based on the use of state-of-the-art monitoring techniques, applied to generate an understanding of basic fluvial processes in such a large regulated river. This paper first describes how contemporary sediment transport 
and associated processes have been analysed and, second, how knowledge generated from this work has informed the development FFs and aided adaptation of their design to the evolving needs of a complex system such as the Ebro.

\section{The River Ebro}

\subsection{The Basin}

The Ebro is the largest river in the Iberian Peninsula flowing into the Mediterranean Sea (Fig. 1A). It drains ca. $85500 \mathrm{~km}^{2}$. The Cantabrian Ranges and the Pyrenees in the N, the Iberian Massif in the SE, and the Catalan Ranges in the E form the natural limits of the catchment. The basin altitude varies from above $3400 \mathrm{~m}$ a.s.1. to sea level (Fig. 1B). The Ebro flows NW-SE along its main axes from the Cantabrian Ranges to the Mediterranean Sea $(910 \mathrm{~km})$, where it forms a delta, one of the most important wetlands of the western Mediterranean region.

From a hydro-climatic perspective the Ebro basin is highly contrasting. Topography influences the climate not only in terms of total precipitation, but also in its temporal variability throughout the year. Mean annual precipitation is $600 \mathrm{~mm}$, ranging from $2000 \mathrm{~mm} \mathrm{y}^{-1}$ in the Pyrenean areas to less than $300 \mathrm{~mm} \mathrm{y}^{-1}$ in the dry interior depression. Rainfall is a highly important determinant of river flow regime. Streams from the Cantabrian Ranges show perennial regimes due to the Atlantic character of the region; in contrast, flow regimes of the Pyrenean tributaries are marked by the snowmelt that yields water maxima in spring and a relatively constant flow in summer; the Iberian tributaries have rainfall-based flow discharges (Q) with two annual maxima (in spring and autumn) and a minimum in summer, when river flow frequently ceases altogether. The Ebro mainstem, as the ultimate water drainer, represents the hydrological integrator of the basin, experiencing snowmelt in spring, flood flows following rainfall thunderstorms in autumn and minimum discharge (Q) in summer. Mean Q in Tortosa (the lowermost gauging station) for the period 1912-2013 is $436 \mathrm{~m}^{3} \mathrm{~s}^{-1}$, a value equating to $13750 \mathrm{hm}^{3} \mathrm{y}^{-1}$ (i.e. $\mathrm{hm}^{3}=1 \times 10^{6} \mathrm{~m}^{3} ; \mathrm{SD}=5475 \mathrm{hm}^{3} \mathrm{y}^{-1}$ and $\mathrm{CV}=0.4$, where SD is the standard deviation and $\mathrm{CV}$ the coefficient of variation). The highest recorded annual water yield is $30821 \mathrm{hm}^{3}$ (1914-1915), while the minimum is 4284 $\mathrm{hm}^{3}$ (1989-1990). Annual runoff is $160 \mathrm{~mm}$, yielding a basin runoff coefficient of 0.25 . The maximum peak Q recorded in Tortosa is ca. $12000 \mathrm{~m}^{3} \mathrm{~s}^{-1}$ estimated by Novoa (1984) for the 1907 flood.

River regulation in the Ebro Basin increased progressively during the $20^{\text {th }}$ century, especially between 1940 and 1975 when most dams were constructed. Nowadays, 187 dams impound approximately $2 / 3$ of the annual runoff; 25 of the reservoirs in the catchment have a capacity larger than $50 \mathrm{hm}^{3}$, and represent $90 \%$ of the total basin storage capacity (Batalla et al., 2004). The largest dams in the Ebro mainstem are Ebro and Mequinenza, located on two major river bends, and have capacities of 540 and $1534 \mathrm{hm}^{3}$ respectively. Other relevant dams are Yesa (holding a current capacity of $446 \mathrm{hm}^{3}$ ) in the River Aragón and Canelles in the Noguera Ribagorçana $\left(678 \mathrm{hm}^{3}\right)$. The Mequinenza-Ribarroja-Flix dam complex (hereafter MRFDC), located in the lower 


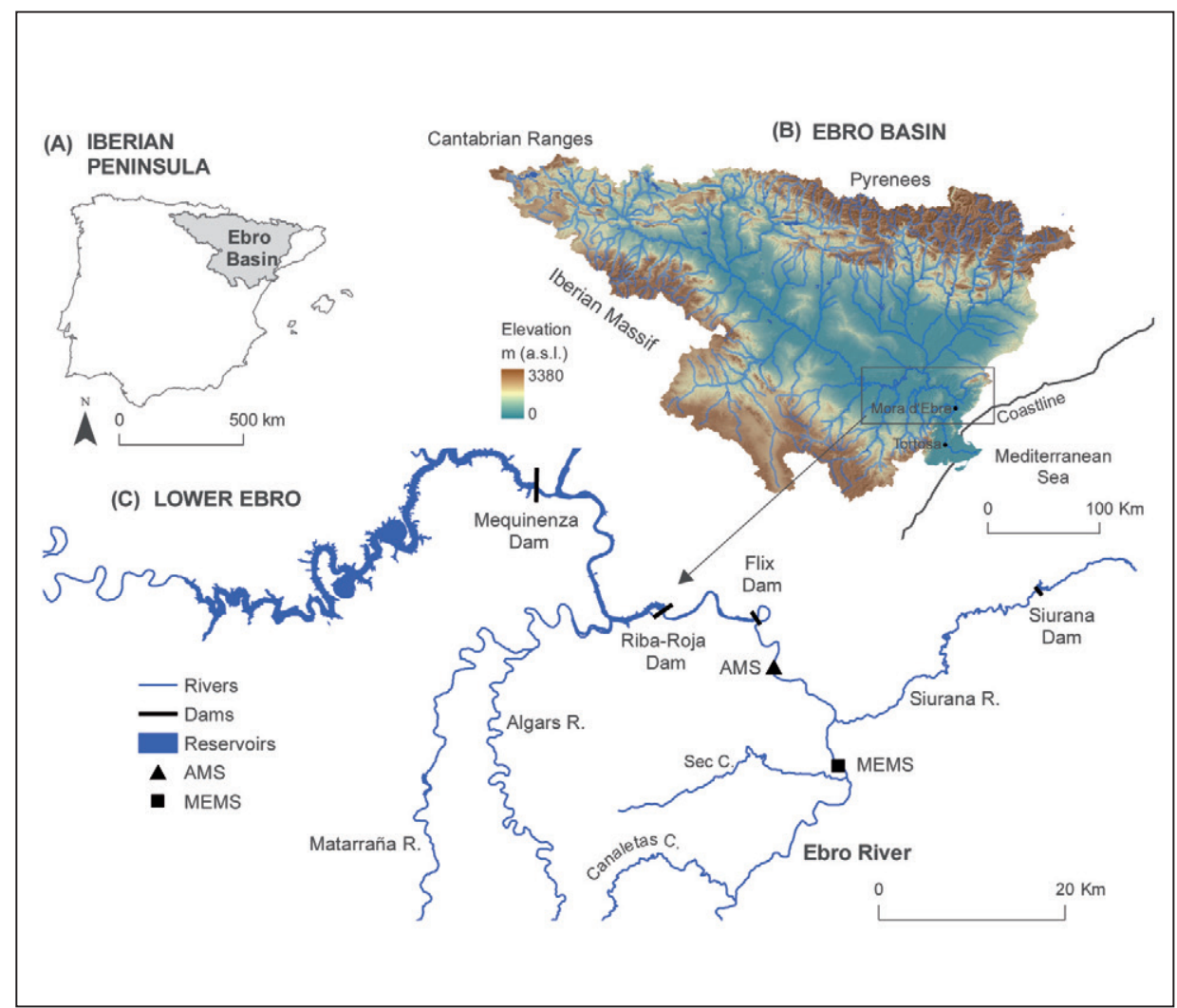

Figure 1. Location of the lower River Ebro in the Iberian Peninsula (A) and in the Ebro basin $(B) ;(C)$ General map of the lower Ebro showing the location of the MRFDC and the main monitoring sections.

Ebro, constitutes the largest in the whole basin (i.e. total storage capacity of $1.7 \mathrm{~km}^{3}$ ), regulating $97 \%$ of the basin area (Fig. 1C).

\subsection{The Lower Ebro}

In this study we considered the lower Ebro as the river reach located downstream of MRFDC (Fig. 1C). In this reach the flow is most influenced by the Pyrenean tributaries characterised by a maximum of $\mathrm{Q}$ in March $\left(695 \mathrm{~m}^{3} \mathrm{~s}^{-1}\right.$ i.e. related to the snowmelt and spring rains in the headwaters) and minima in August and September $\left(150 \mathrm{~m}^{3} \mathrm{~s}^{-1}\right)$. The reach between the Flix Dam and the Ebro Delta extends for ca. $115 \mathrm{~km}$ and has low sinuosity (i.e. 1.15), although in some parts of its course sharp bends occur. Channel width ranges from $80 \mathrm{~m}$ to more than $160 \mathrm{~m}$, and mean slope is $2.5 \times$ $10^{-4}$. The main tributary downstream of the Flix Dam is the River Siurana; this tributary is affected by dams in its headwaters and gravel mining in the lowland part of the 
catchment, and so rarely delivers water and sediment to the Ebro. Two other tributaries (the Sec and the Canaletes creeks) have their confluences with the Ebro in the reach. Both are ungauged, ephemeral and flashy, and are important because of their suspended sediment contribution to the River Ebro during torrential rainfall events. However, their sediment loads are not enough to compensate the sediment deficit that the Ebro experiences due to the numerous upstream mainstem reservoirs which trap sediment.

Vericat and Batalla (2004) estimated a sediment trapping efficiency of MRFDC at around 90\% (based on the Brune [1953] method). A similar percentage had been previously estimated by Avendaño et al. (1997), based on reservoir sedimentation, and Sanz et al. (1999), based on infrequent sampling and most recently by Vericat and Batalla (2006) based on frequent monitoring. The sediment deficit of the reach has also been reflected in a series of studies (e.g. Varela et al., 1986; Palanques, 1987; Guillén and Palanques, 1992; Roura, 2004; Negrel et al., 2007; Tena et al., 2011) that have revealed a trend of decreasing sediment yield in the last century up to two orders of magnitude. Recently Batalla and Vericat (2011) quantified the changes in the sediment load of the whole basin during the $20^{\text {th }}$ century and related this t to river regulation and changes in land use. Of particular interest for this research is the decrease in high flows in the lower Ebro; Batalla et al. (2004) reported that frequent floods (i.e. $\mathrm{Q}_{2}$ to $\mathrm{Q}_{25}$ ) have been reduced by around $25 \%$. Altogether, the lack of sediment and the reduction of floods have substantially modified the river's morphosedimentary dynamics. This is reflected in increased river bed degradation (Vericat and Batalla, 2006), revegetation of formerly active bar areas (Batalla et al., 2006), and riverbed armouring (Vericat et al., 2006).

One of the most visible consequences of aforementioned hydrological and sedimentary changes in the lower Ebro is the proliferation of macrophytes in the channel (Batalla and Vericat, 2009). The colonization of this aquatic vegetation has important hydraulic effects in open channels, changing flow resistance (Green, 2005; Nikora et al., 2008) and causing water velocity attenuation (Dodds and Biggs, 2002). The additional flow resistance can lead to changes in wetted channel areas (e.g. Wilcock et al., 2009; see Prats et al., 2009 for specific insights in the lower Ebro) and, ultimately, changes in flood conditions. Uncontrolled growth of macrophytes in the lower Ebro affects water uses (e.g. abstraction), river navigation and the operation of nuclear and hydropower plants. In addition, the spread of the blackfly (Simulium sp.) has been associated with the increased density of macrophytes (e.g. Ibañez et al., 2008). In some of the Ebro main tributaries (e.g. Segre) the development of extensive, dense macrophyte stands has been acknowledged as an important environmental problem, with both ecological and socioeconomic consequences.

\section{Monitoring sediment transport and associated processes}

Hydrological and morphosedimentary variables have been monitored in the lower Ebro in order to quantify sediment transport and understand the associated fluvial dynamics in the reach. Fig. 2 summarizes the experimental design and field techniques deployed during the 2002-2013 study period. 


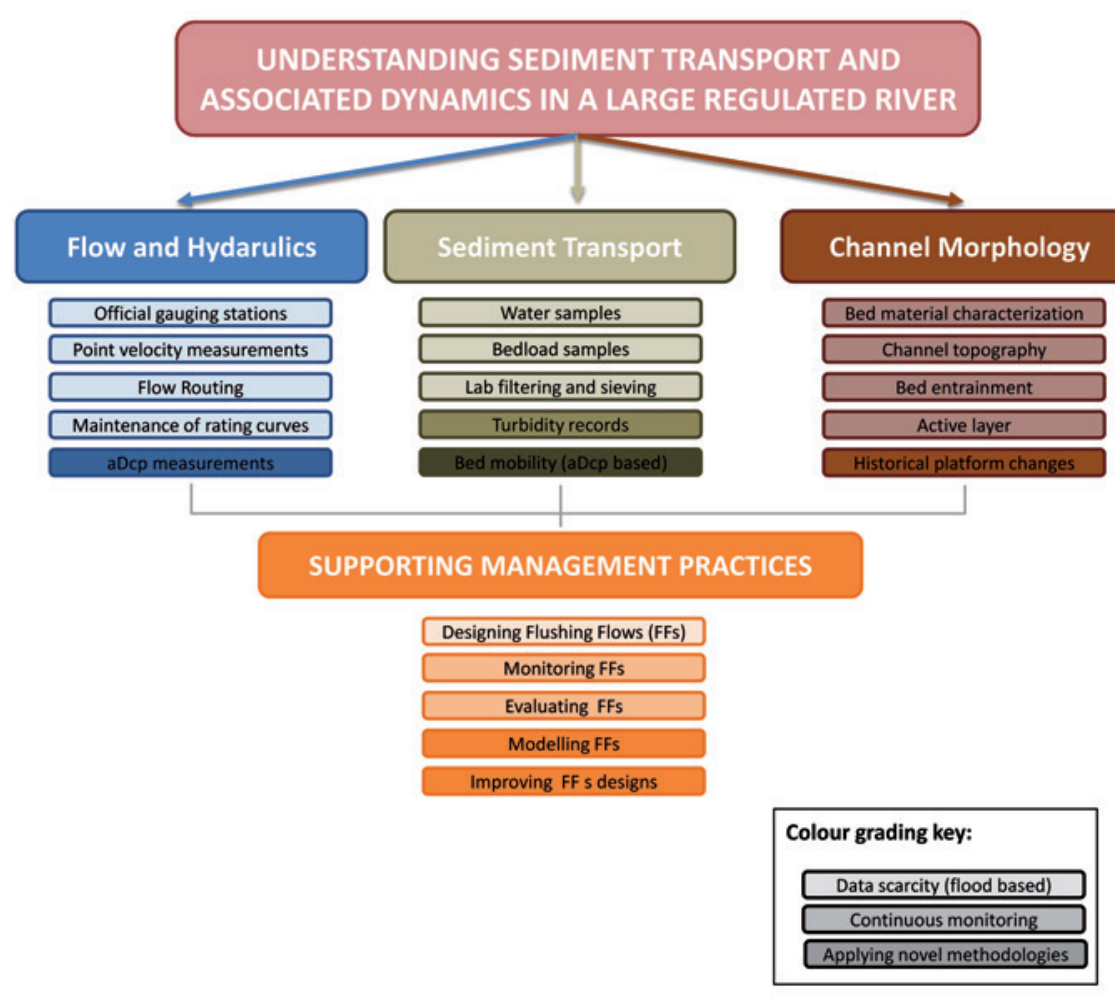

Figure 2. Methods and techniques followed to monitor sediment transport and associated dynamics in the lower Ebro over the 2002-2013 study period.

\subsection{Flow measurements}

Flow recorded by $\mathrm{CHE}$ has been one of the main data sources employed in this research. The main gauging stations used were Ascó (EA163; AMS in Fig. 1C) and Tortosa (EA027, see location in Fig. B). Here, water stage (h) is measured every 15 minutes by means of an OTT Water Stage Recorder, and then transformed into Q by means of specific h/Q rating relations. Q data are available at http://www.oph.chebro.es; real time data can be found online at http://www.saihebro.com. In sections where official data were not available (as in the case of the Móra d'Ebre monitoring sections i.e. MEMS as per Vericat and Batalla, 2006; see Fig. 1C for exact location) water level was logged by means of capacitive water stage sensors (TruTrack ${ }^{\circledR}$ WT-HR). Flow stage was recorded at 15 min intervals. Water stage measures were then transformed into Q by means of stagearea methods (i.e. WinXSpro ${ }^{\circledR}$ ). Additionally, and in order to validate discharge estimates, hydrographs obtained from the closest official gauging station (e.g. Ascó) were routed to MEMS following the Muskingum method (i.e. Shaw, 1983). At a single vertical discharge, measurements were also used to corroborate flood hydrographs. Flow velocity was 
measured from a bridge by means of an OTT C31 current meter which was attached to a cable-suspended US DH74 sampler. Mean velocities were calculated from velocity profiles and subsequently used to verify routed discharges from upstream gauging stations (see Vericat and Batalla, 2006 for specific technical details). Recently, an ADCP River Surveyor M9 ${ }^{\circledR}$ (Sontek; Fig. 3B) has been used at Ascó; these discharge values have been used to inform changes in the official $\mathrm{h} / \mathrm{Q}$ rating relation for the gauging station here. The use of this acoustic method, in addition to flow velocities (Fig. 3A), provides bathymetric data (Fig. 3A), and information on sediment transport (Figures 3C and D).
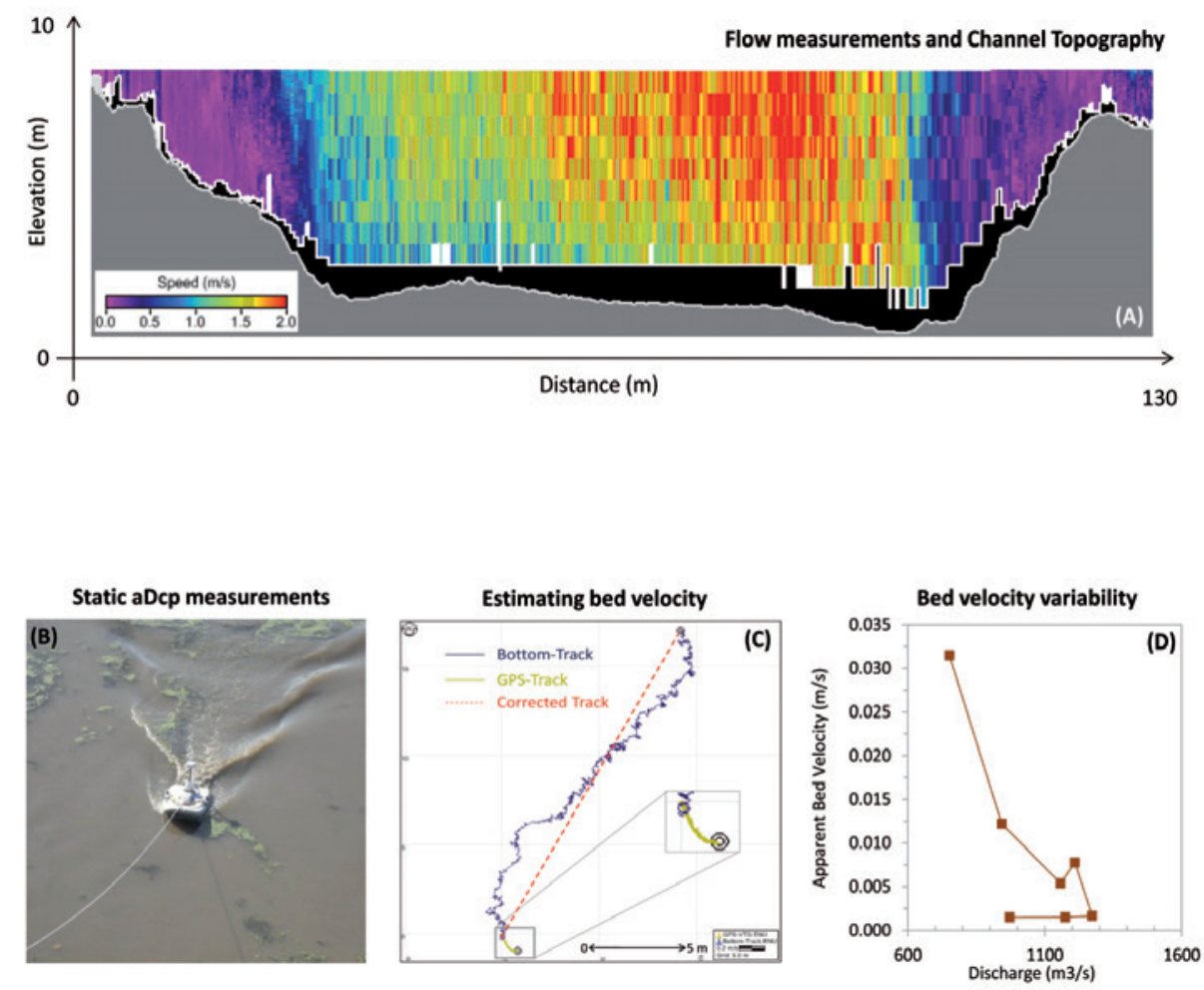

Figure 3. (A) Flow measurements and Channel Topography obtained by aDcp; $(B, C, D)$ sequence of the process followed to obtain Bed velocity and Bed velocity variability by means of aDcp (River Surveyor M9 $9^{\circledR}$, Sontek).

\subsection{Sediment Transport Monitoring}

Three different sampling schemes have been employed over the study period. The first (during the 2002-2004 period) involved direct measurements of both suspended sediment and bedload. Second, between 2005 and 2008 sampling was still based in direct measurements, but only suspended sediment was measured. Third, sampling of suspended sediment was continued through the period 2008-2012, and was based on 
continuous turbidity records complemented with direct sampling for calibration. The different sampling methods in relation to transport mode are described in the sections below.

\subsubsection{Suspended Sediment}

Manual samples were collected intensively during individual flood events and routinely (weekly or fortnightly) during periods of low flow. Cable-suspended, depthintegrated USGS manual samplers (e.g. DH-74, DH-59) were operated from bridges (Móra d'Ebre and Ascó, mainly) using a manual and automatic cranes. Samples were taken from different verticals across the section every 15-30 min during floods; a single sample from the central vertical of the cross section was obtained during low-flow conditions. Hydraulic measurements were taken simultaneously at the same verticals where the water sampling was carried out on some sampling occasions (for more details see Vericat and Batalla, 2006). Bottles were usually filled up to the $75-90 \%$ of their total capacity (1 litre), depending on the sampling conditions (e.g. water stage). Samples were subsequently filtered using $1.2 \mu \mathrm{m}$ pore size cellulose filters. Overall, 1214 depth integrated water and suspended sediment samples were collected in the lower Ebro: 2002-2004 (414 samples), 2005-2008 (200 samples) and 2008-2011 (600 samples). Suspended sediment concentration (SSC) between 2008 and 2011 was obtained from water turbidity data. Turbidity series were obtained from the water quality stations of CHE and from the authors' own turbidity probes. Data supplied by CHE were recorded by means of high range $\mathrm{Hach}^{\circledast}$ SS6 turbidity probes, while we used McVann ${ }^{\circledast}$ Analite turbidity probes in our sections. In both cases turbidity was recorded every 15 minutes. Turbidity does not have direct transformation to SSC, but can be converted by means of a calibration procedure; for this we used water samples taken at the same place where probes were installed. The use of turbidimeters has represented a notable advance in the understanding of the suspended sediment dynamics of the lower Ebro. The continuous register of SSC has allowed examination of local dynamics that otherwise would have been impossible; for instance, point contributions of peak SSC from the River Siurana, despite being most of the time hydraulically disconnected from the mainstem Ebro were evident in the turbidity data (Fig. 4).

\subsubsection{Bedload}

Bedload was sampled in MEMS during competent flows (i.e. floods) at the same vertical as suspended sediment. Bedload was taken by means of a 76-kg cable suspended Helley-Smith sampler with a 152-mm intake (Fig. 5A) and an expansion ratio of 3.22 (i.e. ratio of nozzle exit area to entrance area). Due to its weight, the bedload sampler was operated from a bridge using an automatic crane. In order to keep sampling efficiency as high as possible, sampling time did not exceed 5 min, thus preventing the sampler bag being filled to more than $50 \%$ of capacity (as per Emmett, 1980; Habersack and Laronne, 2001). Sampling interval was $30 \mathrm{~min}$; samples were taken to the laboratory, where they were dried, sieved and weighed to obtain the total mass and grain size distribution of bedload. A total of 173 samples were analysed for the 2002-2004 period (Fig. 5B). 

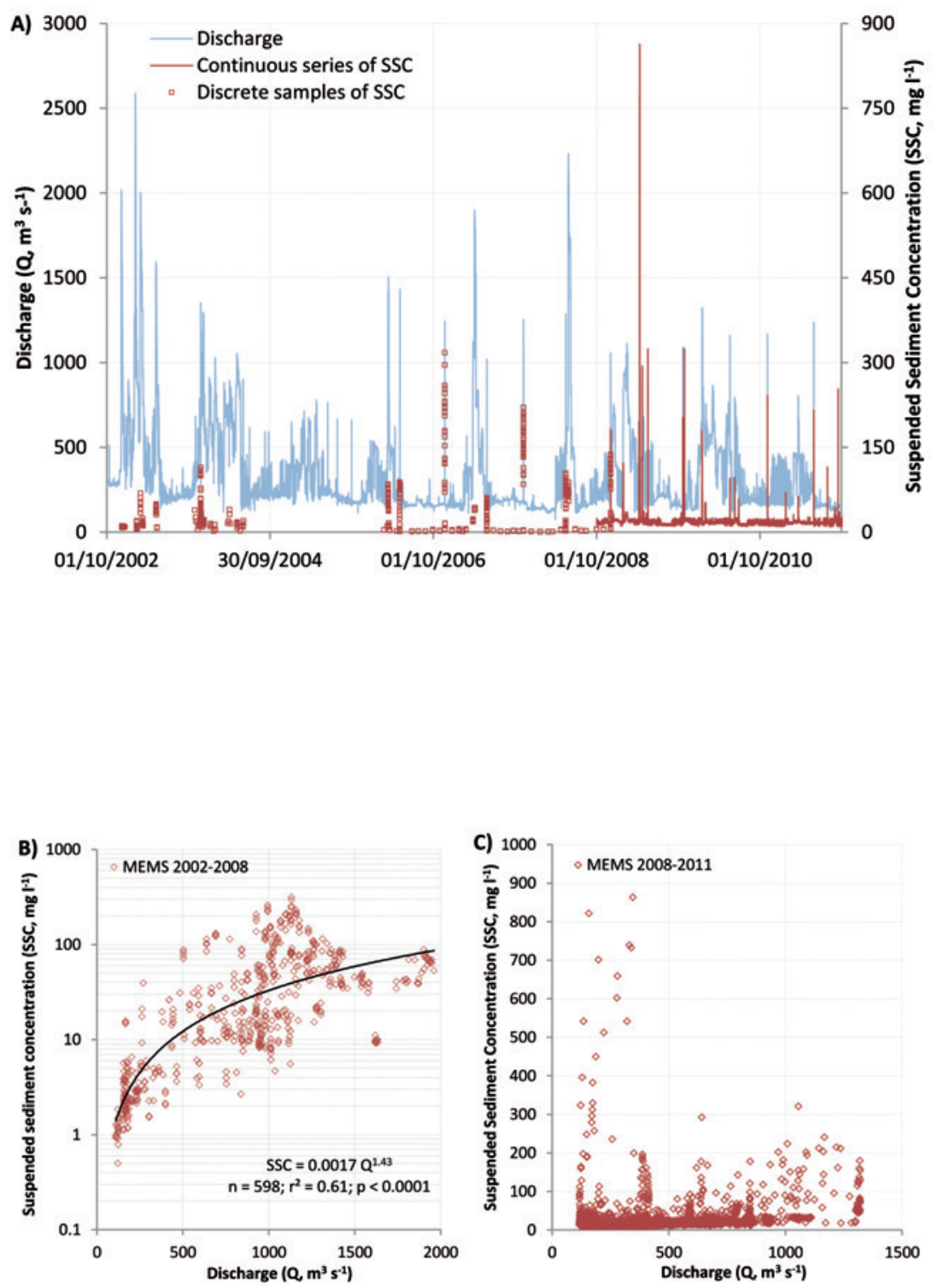

Figure 4. (A) Discharge ( $Q$, blue) and suspended sediment concentration (SSC, red) obtained by direct sampling (squares) and transformed from turbidity (line) for the whole period (2002-2012) at Móra d'Ebre Monitoring sections (MEMS). (B) Rating curve between discharge $(Q)$ and suspended sediment concentration (SSC) from direct sampling and (B) from continuous series at the Móra d'Ebre monitoring section (MEMS). 

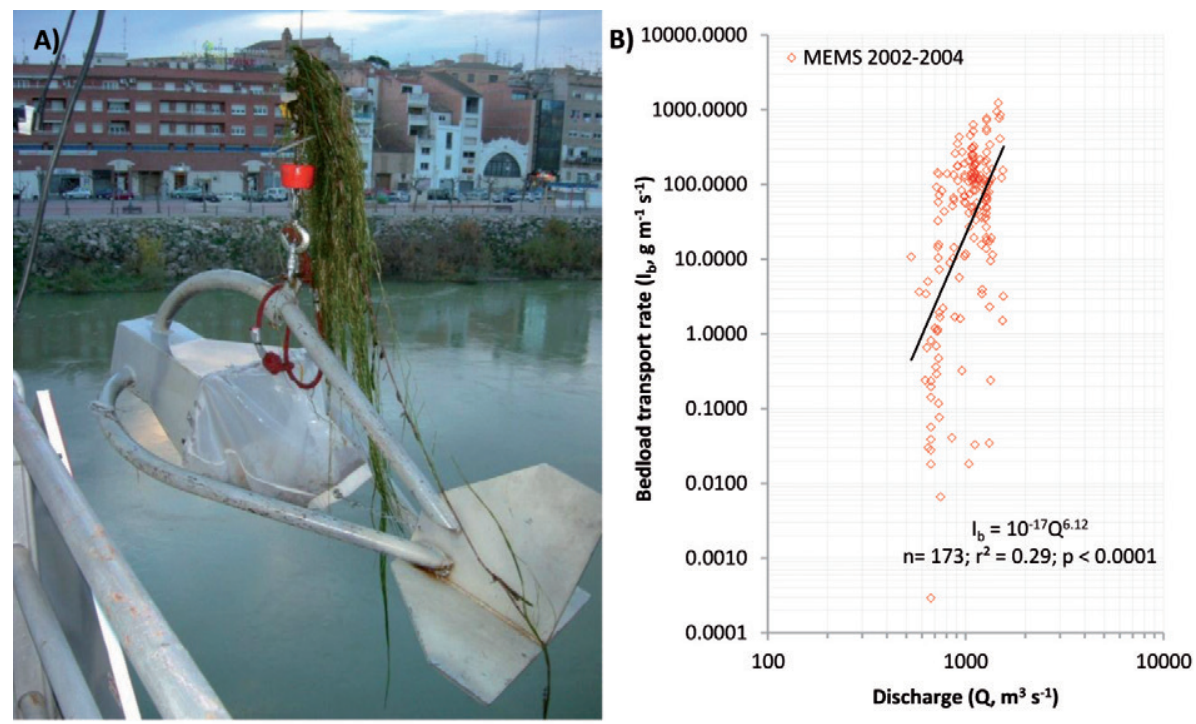

Figure 5. (A) Cable suspended Helley - Smith sampler (152-mm intake) and (B) Rating relation between Bedload transport rate (Ib) and Discharge $(Q)$ at the Móra d'Ebre monitoring section (MEMS).

\subsection{Channel morphology}

A variety of methods have been applied to study sedimentary processes and channel morphology below MRFDC. Surveys were carried out mainly on active river bars. On each bar, bed areas and lines of cobbles were painted and scour chains installed. Moreover, grain-size distributions for both surface and subsurface river-bed material and topographic surveys were undertaken before and after floods. Data were used to examine bed dynamics and structure, particle entrainment, the active layer, bed changes and erosion deposition processes. Historical channel changes associated with dam closure have also been analysed by means of aerial photographs.

Bed-material characterisation was based on the analysis of particle size distribution. Surface river-bed materials were sampled using the pebble count method (e.g. Wolman, 1954; Rice and Church, 1996). A minimum of 100 stones per section were measured. The surface layer was also sampled using the area-by-weight method (Kellerhals and Bray, 1971). This method allows the determination of the percentage of the fine material (i.e. particles finer than $8 \mathrm{~mm}$ ), a fraction that is underestimated by the pebble count method. Subsurface material was sampled by the volumetric method (Church et al., 1987) after removal of the surface layer. Area-by-weight and volumetric samples were sieved at 1/2 phi-intervals and weighed in the field (Fig. 6C and D). Samples containing wet material were taken to the laboratory and dried prior to sieving and weighing to obtain the grain size distribution (Fig. 6E). 
Bed entrainment was studied by means of painted areas and magnetic tracers. Painted surface bed areas of $1 \times 1 \mathrm{~m}$ and lines consisting of at least 9 painted particles were placed in several active bars of the reach (Fig. 6A). Painted areas and lines were located at sedimentary equivalent positions, namely bar head. Painted lines were placed one metre upstream of the painted bed areas and were painted in a different colour. Particle sizes in the painted lines ranged from 8 to $128 \mathrm{~mm}$ (as measured by the size of the $b$ axis in $1 / 2$ phi increments). These methods allow assessment of the mobility of grain-size fractions in relation to the magnitude of flood events. Scour chains were also deployed to determine erosion/deposition in the active areas (Fig. 6B); pairs of scour chains (1 m long and $15 \mathrm{~mm}$ thick) were positioned near the painted areas and surveyed before and after floods to determine the order of magnitude of riverbed erosion and deposition.
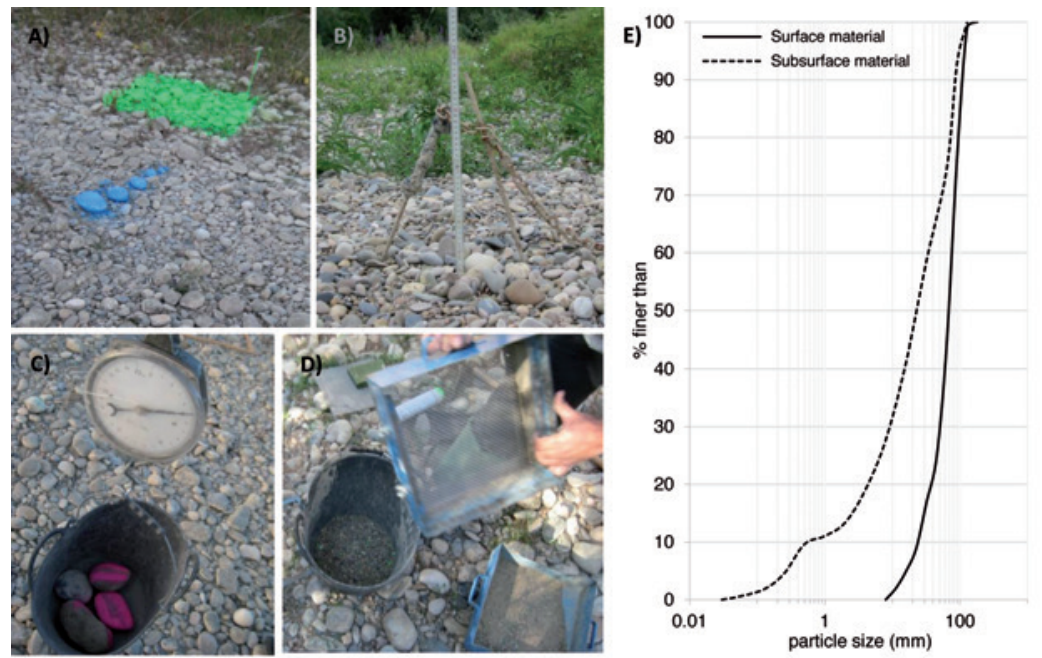

Figure 6. Sequence of photographs showing (A) painted line and area, (B) scour chains and different stages of volumetric method sampling as $(C)$ weighting and $(D)$ sieving, and $(E)$ surface and subsurface grain size distributions in the Móra d'Ebre Monitoring Section.

Finally, historical changes in channel planform were assessed through image processing and analysis. Evolution of river morphology and vegetation encroachment were analysed by means of a series of aerial photographs and orthophotos taken before (1927 and 1956) and after (1995, 1999 and 2002) MRFDC closure. Images were processed using ArcGis $^{\circledR} 9.3$ and MiraMon ${ }^{\circledR}$. Consecutive images of the same reaches and for different time periods had to be superimposed. For this, images of the 1927, 1956 and 1995 series were geometrically corrected to give them real coordinates, taking the 1999 air-photo series as reference (see Sabaté, 2012 for a detailed methodological description). In the analysis, special attention was paid to the differentiation between active and vegetated areas. Classes encompassing different vegetation cover and structure were established and used to determine progressive vegetation encroachment. Changes in channel width were also documented. An example of the analysis can be seen in figs. 7A and B. 

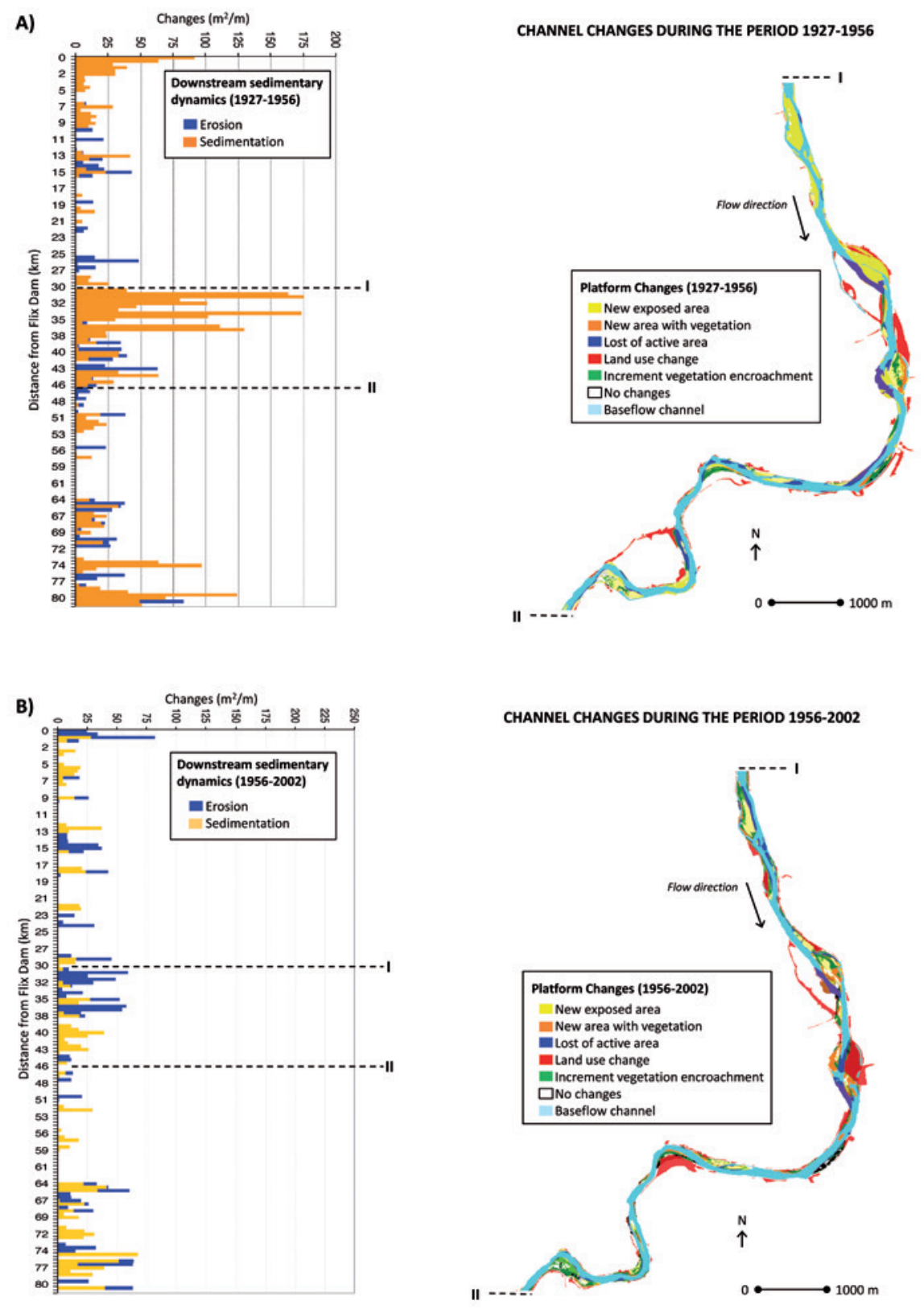

Figure 7. (A) Channel changes during the period 1927-1956 (before dams), when sedimentation processes dominated mainly due to tributaries and upstream reaches contribution; and $(B)$

Channel changes for the period 1956-2002 (after dams) in which sediment erosion predominate over sedimentation highlighting the sediment starvation experienced by the reach due to sediment trapping in the upstream MRFDC (after Sabaté, 2012). 


\section{Flushing flows: an adaptive design for an evolving river}

\subsection{Rationale}

Flushing flows have been widely used for channel maintenance purposes (as per Kondolf and Wilcock, 1996). In the case of the lower Ebro, such artificial releases were designed with the main aim of controlling aquatic vegetation growth and maintaining certain sedimentary activity in the channel downstream from MRFDC (Fig. 1). Regulation has altered river morphology and favoured uncontrolled growth of macrophytes (Palau et al., 2004). Low and constant Q (e.g. Green, 2005), together with low SSC and the consequent increase in light availability (e.g. Kemp et al., 1983), and the lack of sedimentary activity in the channel, have all been described as the main causes for such proliferation (e.g. Batalla and Vericat, 2009). These plants root on the surface gravels to a depth of 5 to $10 \mathrm{~cm}$; thus, in theory they can be dislodged and removed through mobilization of gravels in the active layer equal to the rooting depth (Batalla et al., 2006). Flushing flow hydrographs were therefore designed based on riverbed material entrainment: information on bed-material transport and riverbed characteristics and dynamics obtained by Vericat et al. (2006) was used as the basis for FF design. Calculations were based on Shields (1936) entrainment function for gravels up to $90 \mathrm{~mm}$, equal to the $\mathrm{D}_{95}$ of the coarse surface layer in the study reach (Vericat et al., 2006). For these calculations, a critical value for entrainment $\tau_{c}=0.045$ was used, which has been identified as the likely threshold when grain sizes within sediment mixtures are mobilized within a narrow range of shear stress (Church, 2006).

Water depth was the key parameter used to design FF hydrographs. Critical shearstress was transformed into water depth, which in turn was used to estimate the required $\mathrm{Q}$ based on the h/Q rating curve of the AMS (see Fig. 1 for location), the closest section to the Flix Dam and representative of the typical channel morphology of the lower Ebro (i.e. single-threat low-gradient channel on a gravel bed). Resulting peak flows were equivalent to 1.5-2-year flood of the river's post-dam flow series (i.e. 1970 to present). This $\mathrm{Q}_{1.5-2}$ (where $\mathrm{Q}_{\mathrm{i}}$ is the discharge associated to ${ }_{i}$ years recurrence interval) has been adopted previously as a design criteria for channel maintenance flows (Kondolf, 1998). The resulting flood hydrographs have a characteristic steep rising limb, which is thought to aid efficient removal of macrophytes because the initial surge actively scours the riverbed (Rørslett and Johansen, 1996). Batalla and Vericat (2009) indicated that the flashiness of FFs (the rate at which Q increases) is one or order of magnitude higher than that observed during their natural counterparts (100 and $10 \mathrm{~m}^{-3} \mathrm{~s}^{-1} \mathrm{~h}^{-1}$, respectively). FF releases on the Ebro were performed mostly in May and November, when the water availability is high and the demand for HEP production is still not too important (as in winter). The design of FFs is constrained by dam operation, i.e. water storage and hydropower production (Batalla and Vericat, 2009), and also by the need to minimize risk of local flooding. Observations indicate that a threshold Q of $1800 \mathrm{~m}^{3} \mathrm{~s}^{-1}$ at which riparian villages become inundated should not be surpassed. 
Initially, several flood scenarios were selected, based in different levels of water availability (see Batalla et al., 2006 for further details). The original FF hydrograph adopted for the lower Ebro had double peaks at 1350 and $1150 \mathrm{~m}^{3} \mathrm{~s}^{-1}$ and a total duration of $13 \mathrm{~h}$ (volume $=30.2 \mathrm{hm}^{3}$ ). The first attempt to perform a FF was in December 2002, but it had to be aborted since the artificial release was subsumed by a co-incident natural flood. Since then, sixteen flushing flows have been executed and most have been monitored for hydrology, sediment transport and macrophyte removal. Dam releases have demonstrated significant capacity to entrain and transport sediments, due to sharp peaks yielding energy expenditure rates much high than observed during natural floods (Batalla and Vericat, 2009; Tena et al., 2011). Field data showed that particles up to medium gravel size $\left(\mathrm{D}_{50}\right)$ were entrained and most of the macrophytes in areas close to the Flix Dam were removed (90\%). However, removal efficiency diminished both downstream (e.g. removal values of 5\% were obtained 28 $\mathrm{km}$ downstream; Batalla and Vericat, 2009) and with time (a progressive reduction in macrophyte removal has been observed; unpublished data).

\subsection{Modelling}

A new design was required in order to increase FF effectiveness in macrophyte removal. A higher removal involves higher discharges; however, a FF design with larger peak Q may cause adverse geomorphic effects, most likely bed incision driven by the higher flow competence. Under such conditions, identification of areas where such effects may potentially occur, and prediction of their magnitude, is necessary prior to redesign of the hydrograph. The assessment of the potential geomorphic effects attributed to a characteristic FF was performed using a 2D hydrodynamic and sediment transport model (CCHE2D ${ }^{\circledR}$; National Center for Computational Hydroscience and Engineering, University of Mississippi, US). Model simulation was calibrated and validated using hydrological and sediment transport data collected during and between floods. Model outputs such as critical shear stress and bed changes (net erosion and deposition zones) can be visualized along the $12 \mathrm{~km}$ reach downstream from major dams in Fig. 8. Overall, the typical FF hydrograph does not show severe geomorphic impacts (Tena et al., 2013). In any case, results suggests that channel changes estimated from $\mathrm{CCHE} 2 \mathrm{D}^{\circledR}$ provide a realistic estimate of channel changes which can be used to predict the potential geomorphic effects of FF designs.

Taking into account these results, a new single peak FF hydrograph, with higher peak Q $\left(1450 \mathrm{~m}^{3} \mathrm{~s}^{-1}\right)$, was designed and implemented in the lower Ebro (November 2010). The assessment of this new design with data obtained in the field demonstrated an increased effectiveness in transferring sediment to the downstream reaches as well as in macrophyte removal. However, field observations showed important hydraulic effects related with the excess of macrophytes. The additional rise of the flow resistance led to a notable change in the flood conditions (Prats et al., 2009 for specific insights in the lower Ebro), thus, increasing the flood risk in the riverine villages. 
(A) SHEAR STRESS

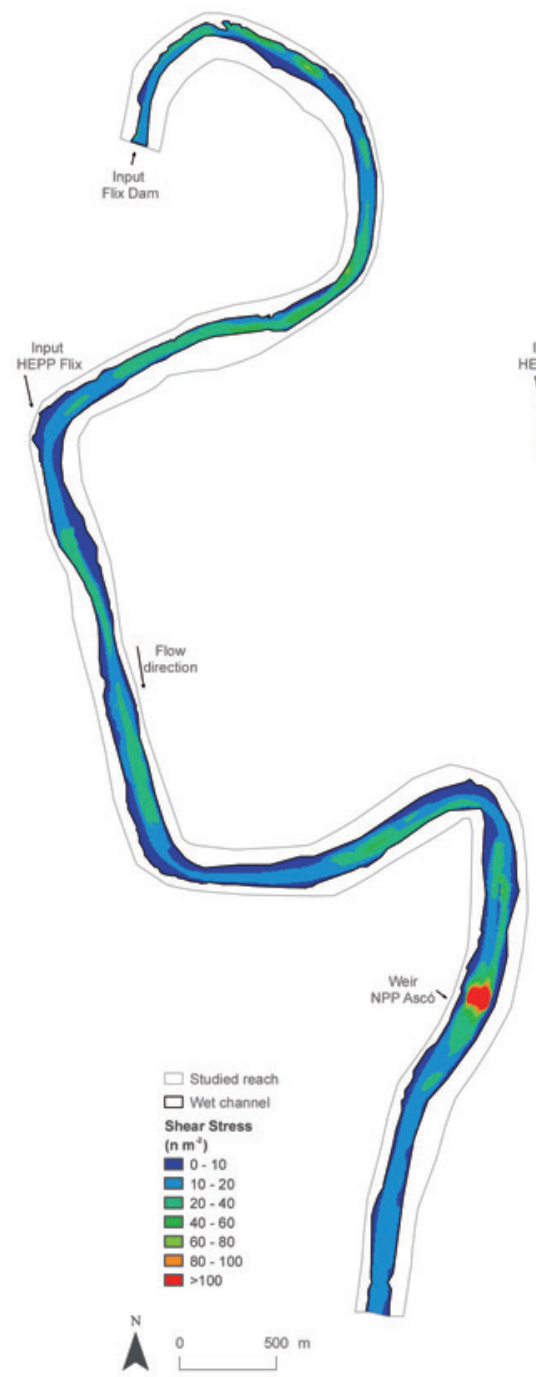

(B) BED CHANGES

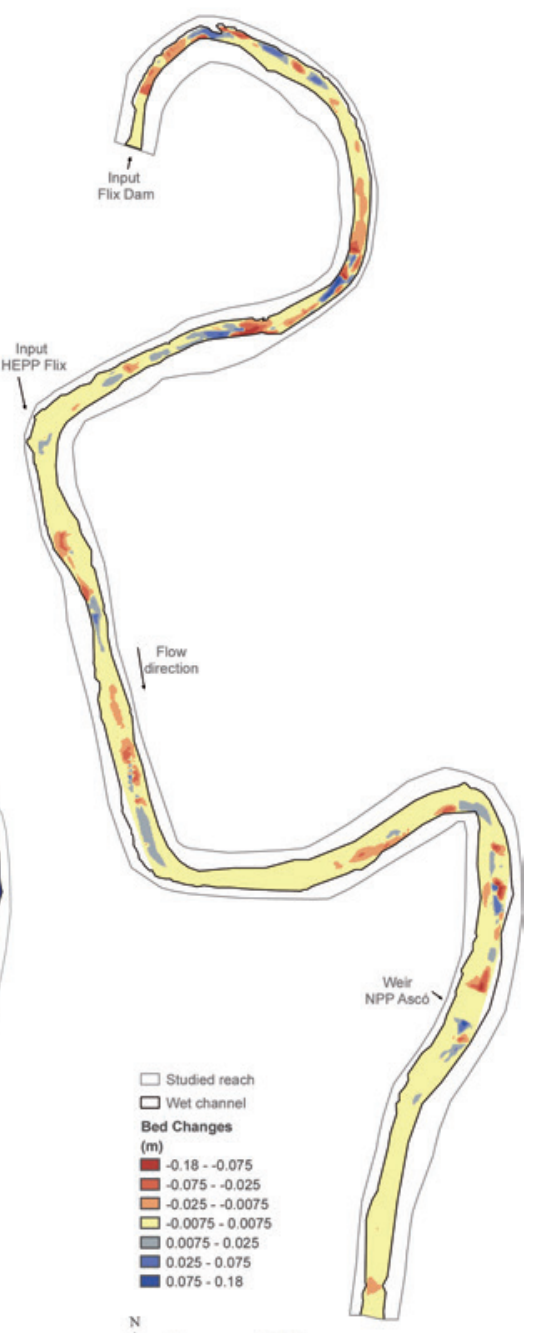

Figure 8. (A) Shear stress and (B) predicted bed changes after simulation for the reach between the Flix Dam and Ascó.

The advantage of using mathematical models for designing hydrographs is the possibility to simulate different flood scenarios to find an optimal design, based on the objectives/constraints of the flood (see the multifaceted control and responses of flushing flows schematically presented in Batalla and Vericat, 2009). In this particular 
case, the new hydrograph had to be designed with a smaller peak discharge while not compromising its effectiveness in sediment transport and macrophyte removal. For this purpose, a chasing wave design was selected (following the approach by Hicks and Goring, 2009). In the case of the lower Ebro, this design consisted of three peaks (i.e. 400,900 and $1200 \mathrm{~m}^{3} \mathrm{~s}^{-1}$ ), the second with a larger peak discharge than the first, and the third with a larger peak discharge than the second; then the second and third peaks were designed to catch the first and strengthen it (Fig. 9). The ideal form would reinforce and form a maximum amplitude surge before the AMS. This design would help to reduce the effects of energy loss associated with the channel routing, thus, optimizing the flow competence. This hydrograph was first implemented in November 2013. The preliminary analysis revealed satisfactory results in terms of flow forecasting (Fig. 9) and suspended sediment transport; macrophyte removal and morphological changes have not been yet assessed.
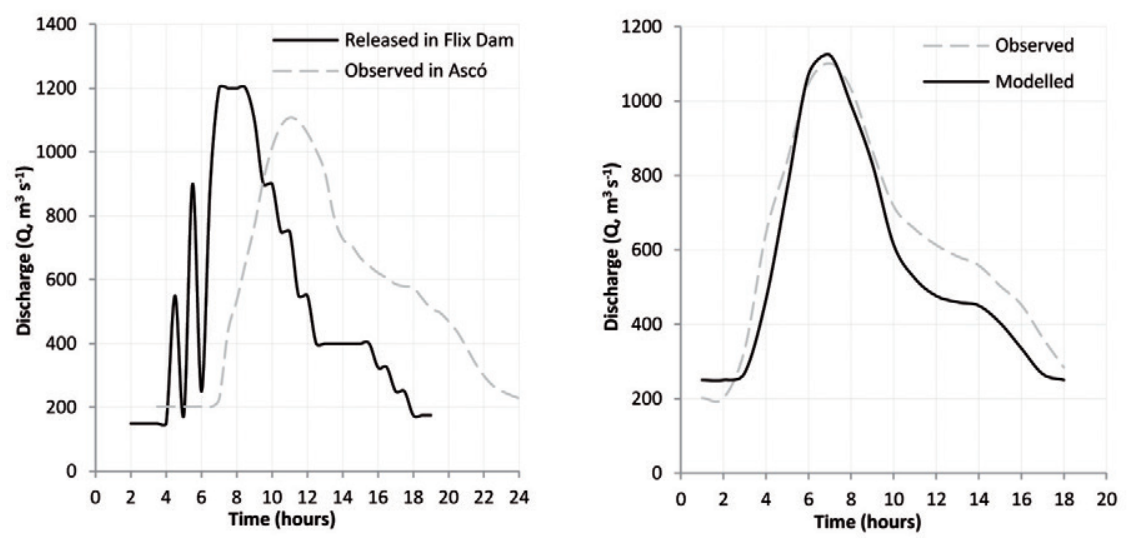

Figure 9. Graphical evaluation of the FF hydrograph. (A) Released hydrograph in the Flix Dam and measured hydrograph at Ascó Monitoring Section (AMS) for the studied 19/11/2013 event, and (B) observed and modeled hydrographs for the same event at AMS.

At the beginning of the work on the Ebro (2002), FFs were seen as a first, almost blind step towards the renaturalization of the river's flow regime. Today, the use of mathematical models, in combination with pre- and post-flood field surveys, indicates improved design and evaluation of the effectiveness of artificial flows in mobilizing the active layer of the channel. The implementation FFs, together with the new insights in sediment transport dynamics acquired during the last decades could be the starting point to design experiments that combine artificial sediment feeding and flow releases that help ameliorate the sediment disequilibrium in the river and between the river and its coastline. 


\section{Overview of findings and prospects}

This paper constitutes an overview of the research carried out over a decade in the River Ebro, one of the largest in the Mediterranean region and highly affected by regulation. Main findings are described in sections 5.1. and 5.2.

\subsection{Hydrology}

The most important physical alteration associated with impoundment of the Ebro basin is the reduction in flood frequency and magnitude. For instance, frequent floods associated with a recurrence interval between 2 and 25 years $\left(Q_{2-25}\right)$ have been specially affected downstream of the Ebro dam (Ebro River). In Tortosa, the lowermost reach of the Ebro River, these floods (main responsible of the river morphology) have been reduced by around 25\% (Batalla et al., 2004). In the same reach, mean Q has also been reduced, from $550 \mathrm{~m}^{3} \mathrm{~s}^{-1}$ before dam closure to less than $330 \mathrm{~m}^{3} \mathrm{~s}^{-1}$ after MRFDC was constructed.

Despite regulation, the lower Ebro still experiences floods, both natural and artificial (i.e. Flushing Flows -FF). Altogether, 26 floods occurred during the 12-years of study, twelve of which were natural floods (i.e. considering natural floods those events floods that are generated in the catchment and are connected to the hydrology upstream from reservoirs, even if they are altered by dam operation); the rest were FFs. Mean duration of natural floods was $333 \mathrm{~h}(\mathrm{SD}=215 \mathrm{~h})$, equivalent to almost 14 days; mean duration of the FFs was $21.5 \mathrm{~h}(\mathrm{SD}=1.3 \mathrm{~h})$. Mean peak discharge of the natural floods was $2005 \mathrm{~m}^{3} \mathrm{~s}^{-1}$, with a maximum of $2649 \mathrm{~m}^{3} \mathrm{~s}^{-1}$. This equates to a recurrence interval of 9 years. In the case of the FFs, mean peak discharge was $1244 \mathrm{~m}^{3} \mathrm{~s}^{-1}$, with a maximum of $1430 \mathrm{~m}^{3} \mathrm{~s}^{-1}$ representing a recurrence interval of 2 years (i.e. $\mathrm{Q}_{2}$ ). One of the main differences between natural and artificial floods was their flashiness. This index measures the rate of discharge increase per unit time and can be considered as a proxy of the rate of energy expenditure in the channel (i.e., FI, Flashiness Index, Batalla and Vericat, 2009). Flashiness of FF was an order of magnitude higher that the natural floods $\left(160 \mathrm{~m}^{3} \mathrm{~s}^{-1} \mathrm{~h}^{-1}\right.$ and $25 \mathrm{~m}^{3} \mathrm{~s}^{-1} \mathrm{~h}^{-1}$, respectively).

\subsection{Sediment transport}

Research allowed estimation that the mean suspended sediment trapping efficiency of Mequinenza and Ribarroja reservoirs is ca. 95\% for suspended sediment (2008-2011 period; i.e. $100 \%$ of the bedload is typically retained too). This sediment would otherwise reach the lowermost reaches of the River Ebro and its delta plain. A similar percentage of suspended sediment retention was estimated by Avendaño et al. (1997), based on reservoir sedimentation, and Sanz et al. (1999), based on discrete sampling. Later, Roura (2004) reported retention in the Mequinenza Reservoir at $95 \%$ from daily suspended sediment data. Below dams, sediment load increases gradually in the downstream direction. However, the annual average load in the lowermost measuring section at Tortosa was still very low $\left(\mathrm{ca} .0 .1 \times 10^{6} \mathrm{t}\right)$. This represents $<1 \%$ of what was transported at the beginning of the $20^{\text {th }}$ century, prior to impoundment and before land use, particularly in the headwater sediment production areas, change. 
The sediment balance of the lower Ebro indicates that net export of sediment predominates over sedimentation. Dam-related sediment starvation effects are evident downstream from the dams, and the sediment balance (i.e. comparison between upstream and downstream monitoring sections) suggests that the majority of sediment is derived from channel and bank erosion. Clearwater released from the Ribarroja and Flix dams scours the riverbed and channel margins. Nonetheless, work has demonstrated that erosion processes are not extraordinarily high (i.e. maximum scour amongst 30 and $60 \mathrm{~mm}$ Vericat and Batalla, 2006; Tena et al., 2013), and, owing to the large amounts of water released from the dams, SSC remains low $\left(<300 \mathrm{mg} \mathrm{l}^{-1}\right)$, even during flood events. SSCs during floods were not high, although these events are responsible for most of the suspended sediment load transported by the river on an annual basis. In some cases, natural floods can transport almost $80 \%$ of the annual load. It has also been demonstrated that sediment delivery from ephemeral tributaries during torrential events was even larger than the sediment transported during FFs (i.e. $5 \%$ of the mean annual load for the period 1998-2008). When total load was measured in the lower Ebro (2002-2004) the ratio between suspended load and bedload was 1.5:1. However, this ratio hides important interannual variability. This variability can be related to the different nature of the flow between the two years; the larger floods in 2002-2003 were able to break up of the armour layer, producing river bed incision and increasing the amount of bedload, while the higher occurrence of frequent discharges during 2003-2004 resulted in the re-establishment of a coarse surface layer, with no incision but still with high capacity to transport suspended sediment. Data also indicate that the channel is relatively unstable and can be completely remobilized during floods of 8 -yr return period or more.

\subsection{Channel Morphology}

Morphological changes associated with impoundment in the Ebro (reduction of frequent floods and lack of sediment due to reservoir trapping) propagate through time. Changes in the river's mass and energy balances lead to the loss of active areas, encroachment of vegetation and associated channel narrowing (e.g. Batalla et al., 2006). The observed increase of macrophytes is another consequence of the Ebro regulation; increases occur as a result of changes in physical and physic-chemical conditions in the river. Controlling macrophytes and maintenance of sedimentary activity in the lower reach of the river were the main reasons to design and implement a FF programme. Flushing flows were monitored and evaluated to avoid undesired geomorphic impacts as well as to improve their effectiveness in macrophyte removal in future years.

\subsection{Flushing Flows}

Flushing flows have demonstrated a higher transport capacity (Batalla and Vericat, 2009; Tena et al., 2011, 2013) than natural floods; this fact is related to their higher flashiness and thus the higher rate of energy increase and expenditure in the river channel. Flushing flow characteristics are strongly conditioned by the season in which they occur. Suspended sediment transport variations mainly depend upon the antecedent conditions, which are influenced by the hydrological characteristics of the 
season. Although several variables can influence the Q-SSC relationship, such as ephemeral tributary contribution, antecedent conditions and sediment-supply exhaustion, the general hysteretic patterns observed in the lower Ebro are mainly controlled by channel routing. The lag between maximum Q and maximum SSC increases in the downstream direction as the flood and sediment waves are routed through the channel. Channel routing is therefore responsible for the hysteresis shape, modifying the hysteresis magnitude and direction from clockwise to counterclockwise in the downstream direction. At a flood scale, it is not possible to attribute the sediment behaviour to a single factor but a combination of them: energy expenditure in the channel, sediment availability, as well as sediment routing and deposition.

\subsection{River management}

Results of this research constitute valuable information for the management of the River Ebro. In addition to monitoring, modelling was applied to assess the geomorphic effects of artificial flushing flow releases (Tena et al., 2013), demonstrating the need for permanent control of the effectiveness and effects of such flows, thus optimising their design. The high transport capacity demonstrated by the FFs (Batalla and Vericat, 2009; Tena et al., 2011; Tena et al., 2013) suggests that their combination with other restoration measures such as sediment injections may benefit the riverine ecosystem, maximizing the sediment delivery to the lowermost river reaches. Within this context, the experience of the National Institute of Water and Atmospheric Research (NIWA) in New Zealand can be evaluated and considered for possible implementation in the lower river Ebro. For example, Hicks and Goring (2009) used modelling to design a flushing flow hydrograph to facilitate the dispersion of sediment accumulated in the confluence of a tributary in the River Moawhango (New Zealand). In the lower Ebro a hydraulic model could be used to forecast the evolution of the wave shape and phase speed associated with various options for flushing flow releases. For instance, designing a ramped wave or a "chasing" wave to form a surge of maximum height at key confluences, favouring the re-suspension of accumulated sediment and its transfer to downstream reaches.

Overall, this work has provided, over the long-term, key information to understand the geomorphological behaviour of a large river that has experienced notable alteration in its flow and sedimentary regimes. This detailed knowledge should be considered as a basis to design and model strategies for future river management, strategies aimed at renaturalization of the river's physical and thus ecological functioning.

\section{Acknowledgements}

This research has been carried out within the framework of a series of research projects funded by the former Spanish Ministries of Education and Science and Innovation between 2002 and 2009 (i.e. REN2001-0840-C02-01/HID, CGL200506989-C02-02/HID, CGL2006-11679-C02-01/HID, CGL2009-09770/BTE) and the Ministry of Economy and Competiveness (Consolider Ingenio 2010 CSD2009-00065); together with research contracts from the Spanish Ministry of Environment, the Catalan 
Water Agency, and the Ebro Water Authorities, through URS-España. The third author had a research grant funded by the Spanish Ministry of Education and Science (FPI Programme 2007-2011). The second author has a Ramon y Cajal Fellowship (RYC2010-06264) funded by the Spanish Ministry of Science and Innovation. Authors would like to thank the University of Mississippi and the National Center for Computational Hydroscience and Engineering (NCCHE) for allowing us to use the CCHE2D $^{\circledR}$ model. Special thanks are due to the Ebro Water Authorities and Endesa Generación SA for their collaborative support, providing assistance, data and useful materials such as Digital Elevation Models and RGB and NIR images. We acknowledge the support given by RIUS members during fieldwork campaigns. Finally, we are grateful to Chris Gibbins for reviewing the final version of the paper.

\section{References}

Avendaño, C., Cobo, R., Sanz, M.E. y Gomez, J.L. 1997. Capacity situation in Spanish reservoirs. In Proceedings of the $19^{\text {th }}$ Congress on Large Dams 74 (52), ICOLD, Florence, pp. 849-862.

Batalla, R.J., Vericat, D. 2009. Hydrological and sediment transport dynamics of flushing flows: implications for river management in large Mediterranean rivers. River Research and Applications 25 (3), 297-314.

Batalla, R.J., Vericat, D. 2011. An appraisal of the contemporary sediment yield in the Ebro Basin. Journal of Soils and Sediments 11, 1070-1081

Batalla, R.J., Kondolf, G.M., Gomez, C.M. 2004. Reservoir-induced hydrological changes in the Ebro River basin, NE Spain. Journal of Hydrology 290, 117-136.

Batalla, R.J., Vericat, D., Palau, A. 2006. Sediment transport during a flushing flow in the lower Ebro River. In Rowan, J.S., Duck, R.W., Werritty, A. (eds.), Sediment Dynamics and the Hydromorphology of Fluvial Systems, IAHS Publication 306, Wallingford, UK, pp. 37-44.

Brune, G.M. 1953. The trap efficiency of reservoirs. Transactions of the American Geophysical Union 34, 407-418.

Church, M., McLean, D.G., Wolcott, J.F. 1987. River bed gravels: sampling and analysis. In Sediment Transport in Gravel-bed Rivers, Thorne, C.R., Bathurst, J.C., Hey, R.D. (eds), John Wiley, Chichester, pp. 43-88.

Church, M. 2006. Bed material transport and the morphology of alluvial river channels. Annual Review of Earth and Planetary Sciences 34, 325-354.

Dodds, W.K., Biggs, B.J. 2002. Water velocity attenuation by stream periphyton and macrophytes in relation to growth form and architecture. Journal of the North American Benthological Society 21(1), 2-15.

Emmett, W.W. 1980. A field calibration of the sediment trapping characteristics of the HelleySmith bedload sampler. US Geological Survey Professional Paper, 1139.

Grantham, T.E., Merenlender, A.M., Resh, V.E. 2010. Climatic influences and anthropogenic stressors: An integrated framework for streamflow management in Mediterranean-climate California, U.S.A. Freshwater Biology 55 (Suppl.1), 188-204.

Green, J. 2005. Further comment on drag and reconfiguration of macrophytes. Freshwater Biology 50, 2162-2166.

Guillén, J., Palanques, A. 1992. Sediment dynamics and hydrodynamics in the lower course of a river highly regulated by dams: the Ebro River. Sedimentology 39, 567-579.

Habersack, H.M., Laronne, J.B. 2001. Bed load texture in an alpine gravel bed river. Water Resources Research 37(12), 3359-3370. 
Hicks, D.M., Goring, D. 2009. Modifying flushing flows in the Mohawango River to mitigate downstream effects. NIWA Client Report CHC2009-164, November 2009.

Hutchinson, S.E., Sklar, F.H., Roberts, C. 1995. Short-term sediment dynamics in a southeastern USA spartina marsh. Journal of Coastal Research 11, 370-380.

Ibáñez, C., Prat, N., Duran, C., Pardos, M., Munné, A., Andreu, R., Caiola, N., Cid, N., Hampel, H., Sánchez, R.F., Trobajo, R. 2008. Changes in dissolved nutrients in the lower Ebro river: causes and consequences. Limnetica 27 (1), 131-142.

Kellerhals, R., Bray, D.I. 1971. Sampling procedures for coarse fluvial sediments. Journal of the Hydraulics Division ASCE 97 (HY8), 1165-1180.

Kemp, W.M., Boynton, W.R., Stevenson, J.C., Twilley, R.R., Means, J.C. 1983. The decline of submerged vascular plants in the upper Chesapeake Bay: summary of results concerning possible causes. Marine Technology Society Journal 17, 78-89.

Kondolf, G.M. 1998. Hungry water: effects of dams and gravel mining on river channel. Environmental Management 21 (4), 533-551.

Kondolf, G.M., Wilcock, P.R. 1996. The flushing flow problem: defining and evaluating objectives. Water Resources Research 32 (8), 2589-2599.

Ligon, F., Dietrich, W.E., Trush, W.J. 1995. Downstream ecological effects of dams: a geomorphic perspective. BioScience 45 (3), 183-192.

Négrel, P., Roy, S., Petelet-Giraud, E., Millot, R., Brenot, A. 2007. Long-term fluxes of dissolved and suspended matter in the Ebro River Basin (Spain). Journal of Hydrology 342, 249-260.

Nikora, V., Larned, S., Nikora, N., Debnath, K., Cooper, G., Reid, M. 2008. Hydraulic resistance due to aquatic vegetation in small streams: field study. Journal of Hydraulic Engineering 134 (9), 1326-1332.

Novoa, M. 1984. Precipitaciones y avenidas extraordinarias en Catalunya. In Jornadas de Trabajo sobre Inestabilidad de laderas en el Pirineo, Barcelona, pp. 1-15.

Palanques, A. 1987. Dinámica sedimentaria, mineralogía y microcontaminantes inorgánicos de las suspensiones y de los sedimentos superficiales en el margen continental del Ebro. $\mathrm{PhD}$ Thesis, University of Barcelona, Barcelona.

Palau, A., Batalla, R., Rosico, E., Meseguer, A., Vericat, D. 2004. Management of water level and design of flushing floods for environmental river maintenance downstream of the Riba-roja reservoir (lower Ebro River, NE Spain). HYDRO 2004: A New Era for Hydropower, Porto, Portugal, 18-20 October 2004.

Petts, G.E. 1984. Impounded rivers: perspectives for ecological management. Wiley, New York, $326 \mathrm{pp}$.

Poulos, S.E., Collins, M.B. 2002. A quantitative evaluation of riverine water/sediment fluxes to the Mediterranean basin: natural flows, coastal zone evolution and the role the dam construction. In S.J. Jones, L.E. Frostick (eds.) Sediment Flux to Basins: Causes, Controls and Consequences, Special Publications 191, Geological Society, London, UK, 227-245.

Prats, J., Dolz, J., Armengol, J. 2009. Variabilidad temporal en el comportamiento hidráulico del curso inferior del río Ebro. Ingeniería del Agua 16 (4), 259-272.

Rice, S., Church, M. 1996. Sampling surficial fluvial gravels: the precision of size distribution percentile estimates. Journal of Sedimentary Research 66 (3), 654-665.

Rørslett, B., Johansen, S.W. 1996. Remedial measures connected with aquatic macrophytes in Norwegian regulated rivers and reservoirs. Regulated Rivers: Research and Management 12 (4-5), 509-522.

Roura, M. 2004. Incidència de l'embassament de Mequinensa en el transport de sòlids en suspensió $i$ la qualitat de l'aigua del riu Ebre. $\mathrm{PhD}$ Thesis, Facultat de Biologia, Universitat de Barcelona, Barcelona, $145 \mathrm{pp}$. 
Sabaté, J. 2012. Disseny i planificació d'una actuació pilot de restauració fluvial al tram baix del riu Ebre en base a l'anàlisi i diagnosi de l'evolució morfològica. Projecte de final de grau d'enginyeria forestal, Escola Tècnica Superior d'Enginyeria Agrària (ETSEA), Universitat de Lleida, Lleida.

Sanz, M.E., Avendaño, C., Cobo, R. 1999. Influencia de los embalses en el transporte de sedimentos hasta el río Ebro (España). In Proceedings of the Congress on Hydrological and geochemical processes in large-scale river basins, HIBAM, Shahin, p. 1985.

Shaw, E.M. 1983. Hydrology in Practice. Van Nostrand Reinhold, London, 539 pp.

Shields, A. 1936. Anwendung der Aehnlichkeitsmechanik und der turbulenzforschung auf die Geschiebebewegung [Application of similarity principles and turbulence research to bedload movement]. Mitteilungen der Preußischen Versuchsanstalt für Wasserbau, 26, Preußischen Versuchsanstalt für Wasserbau, Berlin.

Surian, N., Rinaldi, M. 2003. Morphological response to river engineering and management in alluvial channels in Italy. Geomorphology 50, 307-326.

Surian, N., Cisotto, A. 2007. Channel adjustments, bedload transport and sediment sources in a gravel-bed river, Brenta River, Italy. Earth Surface Processes and Landforms 32, 1641-1656.

Tena, A., Batalla, R.J. 2013. The sediment budget of a large river regulated by dams (the lower River Ebro, NE Spain). Journal of Soils and Sediments 13, 966-980.

Tena, A., Batalla, R.J., Vericat, D., López-Tarazon, J.A. 2011. Suspended sediment dynamics in a large regulated river over a 10-year period (the lower Ebro, NE Iberian Peninsula). Geomorphology 125, 73-84.

Tena, A., Batalla, R.J., Vericat, D. 2012. Reach-scale suspended sediment balance downstream from dams in a large Mediterranean river. Hydrological Sciences Journal 57, 831-849.

Tena, A., Ksiazek, L., Vericat, D., Batalla, R.J. 2013. Assessing the geomorphic effects of a flushing flow in a large regulated river. River Research and Applications 29, 876-890.

Varela, J., Gallardo, A., López de Velasco, A. 1986. Retención de sólidos por los embalses de Mequinenza y Ribarroja. Efectos sobre los aportes al Delta del Ebro, In M. Mariño (ed.), El sistema integrado del Ebro. Madrid, Gráficas Hermes, pp. 200-219.

Vericat, D., Batalla, R.J. 2004. Efectos de las presas en la dinámica fluvial del curso bajo del río Ebro. Cuaternario y Gemorfología 18 (1-2), 37-50.

Vericat, D., Batalla, R.J. 2006. Sediment transport in a large impounded river: the lower Ebro, NE Iberian Peninsula. Geomorphology 79, 72-92.

Vericat, D., Batalla, R.J., García, C. 2006. Breakup and reestablishment of the armour layer in a highly regulated large gravel-bed river: the lower Ebro. Geomorphology 76, 122-136.

Wilcock, P.R., Kondolf, G.M., Matthews, W.V.G., Barta, A.F. 1996. Specification of sediment maintenance flows for a large grave-bed river. Water Resources Research 32 (9), 2911-2921.

Wilcock, R.J., Champion, P.D., Nagels, J.W., Croker, G.F. 1999. The influence of aquatic macrophytes on the hydraulic and physico-chemical properties of a New Zealand lowland stream. Hydrobiologia 416, 203-214.

Williams, G.P., Wolman, M.G. 1984. Downstream effects of dams in alluvial rivers. US Geological Survey, Professional Paper, 1286, 83 pp.

Wolman, M.G. 1954. A method of sampling coarse bed material. Transactions of the American Geophysical Union 35, 951-956. 